\title{
Grevillea wilkinsonii (Proteaceae) a new species from southern New South Wales
}

\author{
R.O. Makinson
}

\begin{abstract}
Makinson, R.O. (Herbarium of the Australian National Botanic Gardens, GPO Box 1777, Canberra ACT Australia 2601; e-mail: rom@anbg.gov.au) 1993. Grevillea wilkinsonii (Proteaceae), a new species from southern New South Wales. Telopea 5(2): 351-358. A new species of the toothbrushinflorescence' group of Grevillea, G. wilkinsonii, allied to G. barklyana and G. longifolia, is described and illustrated. The species is highly endangered and conservation factors are discussed.
\end{abstract}

\section{Introduction}

The species was apparently first noticed by a local naturalist-bushwalker, Mr Tom Wilkinson of Tumut, in the early 1980s. In about 1988, he brought it to the attention of Messrs Simon and Robert Irwin of 'Stoney Creek' Nursery at Goobarragandra. Suspecting it to be new, they referred it in May 1991 to Mr Peter Ollerenshaw of Bywong Nursery, Bungendore, who in turn passed a specimen to the Australian National Botanic Gardens herbarium (CBG). Field investigations have located two threatenened populations with a total of about 150 plants. Both populations have been studied by the author. The description is based on field notes and herbarium specimens, including spirit and rehydrated material.

Grevillea wilkinsonii $R$. Makinson, sp. nov.

Affinis G. barklyanae F. Mueller ex Bentham et G. longifoliae R. Br. a qua frutice minore ad $2 \mathrm{~m}$ alto, foliis anguste oblongis et ordinate spinidentatis et abaxialiter sericeis, conflorescentiis deflexis vel decurvatis, pistillis $14-15 \mathrm{~mm}$ longis et lilacinoroseis, folliculis $8-9 \mathrm{~mm}$ longis, differt.

HolotyPE: New SOUTH WALEs: Southern Tablelands: ... ESE of Tumut, ... along Goobarragandra Road from turnoff just $\mathrm{N}$ of Tumut, R.O. Makinson 865, T. Wilkinson, G. Butler \& J. Briggs, 18 Oct 1991 (CBG 9106647). IsoTYPes: AD, BRI, HO, K, L, MEL, MO, NE, NSW, PERTH, PRE, RSA.

Ascending to erect shrub when young, becoming denser and more spreading with age or in sheltered situations, to $2 \mathrm{~m}$ tall and wide, or rarely with a sprawling trunk to $4 \mathrm{~m}$ long; branches ascending to spreading; branchlets slightly angular-ridged in cross-section, densely subsericeous with pale hairs. Leaves ascending to spreading, petiolate with petioles 5-14 mm long, simple, (5-)10-17 cm long, 8.5-21 mm wide, narrowly oblong or oblong-elliptical, margin flat, regularly dentate with (4-)5-17 small (to $4 \mathrm{~mm}$ long) subtriangular teeth per side, each tooth terminating in a weak spine 1-2 mm long; leaf apex obtuse with a weak point; lowermost $1.5-3.5 \mathrm{~cm}$ of leaf lacking marginal teeth, tapering into the petiole; upper surface of leaf smooth, midgreen (sometimes bronze-purple on juvenile foliage), glabrous or with a sparse inconspicuous indumentum of appressed, dark-coloured two-armed hairs concentrated along the midvein; lower surface silver-sericeous with a dense indumentum of straight two-armed hairs; venation with the midvein and lateral veins moderately conspicu- 
ous on both surfaces, the veins of the lower surface hair-covered, lateral veins ascending at c. $30^{\circ}$ to $40^{\circ}$ to the midvein, one lateral vein to each marginal tooth and sinus. Conflorescences conspicuous, terminal, simple, secund, centripetal, usually deflexed or decurved through up to $120^{\circ}$ in upper part of peduncle or sometimes rachis also gently decurved, 30-80-flowered, with a strong mousey (amine?) odour; peduncles 3-5 mm long, densely tomentose; rachises (20-)35-55 mm long, densely subsericeous to tomentose; floral bracts ovate-cupulate to broadly angular-obovate, $1.5-2.4 \mathrm{~mm}$ long, 1.4-2.0 mm wide, outer surface subsericeous, inner surface glabrous or with an open appressed indumentum, bracts cupped forward in bud stage, spreading and closely pressed to pedicels at anthesis, variably caducous, usually falling in late bud stage but sometimes persistent to anthesis or a little beyond; pedicels $1.5-2.0 \mathrm{~mm}$ long, spreading from rachis, loosely tomentose; torus oblique at $10^{\circ}-20^{\circ}, 1.0-1.2 \mathrm{~mm}$ across (dorsiventrally); perianth narrowly and obliquely ovoid, 1.2-1.5 mm across, outer surface loosely subsericeous with longitudinally aligned straight appressed two-armed hairs, most hairs pale, some reddish; inner surface of perianth glabrous; limb of bud decurved, subglobose, $1.5-1.7 \mathrm{~mm}$ diam.; dorsal tepals $7.5-9 \mathrm{~mm}$ long, 0.6-0.8 mm wide; nectary conspicuous, arcuate, thin along the erose margin, partly enclosed within the torus, $0.9-1.3 \mathrm{~mm}$ high, extending $0.4-0.5 \mathrm{~mm}$ above toral rim, $0.3 \mathrm{~mm}$ thick at level of rim, occasionally (?abnormally - see discussion) deeply divided to base of nectary tissue into two or three distinct subtriangular lobes; pistil 14-15 $\mathrm{mm}$ long; stipe largely concealed by torus and nectary, $0.6-1.0 \mathrm{~mm}$ long, subsericeous; ovary 1.1-1.5 mm long, sericeous with appressed two-armed hairs, hairs mostly pale but some red-maroon and aggregated to form narrow dorsal stripes; ovules attached at or just below the medial position; style in late bud stage looping strongly outward from dorsal perianth suture, glabrous, after anthesis more or less erect except for a sharp forward (ventral) decurvature of c. $45^{\circ}$ at about $2-4 \mathrm{~mm}$ from apex; pollen-presenter broadly and obliquely conical, $0.6-0.7 \mathrm{~mm}$ high, $1.2-1.3 \mathrm{~mm}$ diam., \pm circular in end view with a crenate rim, oblique to line of the style-end at c. $20^{\circ}$, stigma apical and distally off-centre. Fruits follicular, usually one-seeded (one ovule aborting) or rarely two-seeded, obliquely ovoid, 8-9 mm long, 4-5 mm wide (dorsiventrally); style persistent; surface densely subsericeous with straight two-armed hairs, the hairs mostly pale but some reddish brown and aggregated to form conspicuous dorsal stripes and blotches; pericarp $0.4 \mathrm{~mm}$ thick at suture, texture weakly crustaceous. Seeds fatly ellipsoid, 5.0-6.3 mm long, 3.3-3.5 mm wide, 2.5-3.2 mm thick, $0.035-0.038 \mathrm{~g}$ fresh weight; outer face strongly convex, purplish brown, minutely wrinkled; inner face vulviform, a central longitudinal cleft $3.5-4 \mathrm{~mm}$ long formed between two closely adpressed lip-like ridges, the whole of the inner face face covered with a pale waxy substance that is extended at the apex into a friable subtriangular elaiosome c. $0.7 \mathrm{~mm}$ long. Figure 1.

DERIVATION OF EPITHET: The epithet is chosen in recognition of Mr Tom Wilkinson of Tumut, bushwalker and natural history enthusiast, who discovered the species.

VARIATION: The species occurs in two disjunct populations on the banks of the Goobarragandra River. Although clearly conspecific, and separated by only about 3.5 river-kilometres (c. $2.5 \mathrm{~km}$ direct line), the populations show tendencies towards consistent morphological differences which are probably genetically fixed. Clonal growth trials are not yet far advanced enough to confirm that the differences are transmitted to progeny. The most obvious differences between the upstream 'Goobarragandra' population and the downstream 'Lacmalac' population (using nearby place-names for convenience) are in leaf length ((5-)8-12.5 cm as against (7-)9.5-17 cm respectively); number of leaf-teeth (probably co-variant with leaf length: (4-)5-11 teeth per side as against (7-)13-15 per side); leaf-tooth size (up to $2 \mathrm{~mm}$ amplitude as against up to $4 \mathrm{~mm}$ ), and conflorescence deflexion in flowering stage (normally $90^{\circ}-120^{\circ}$, against 


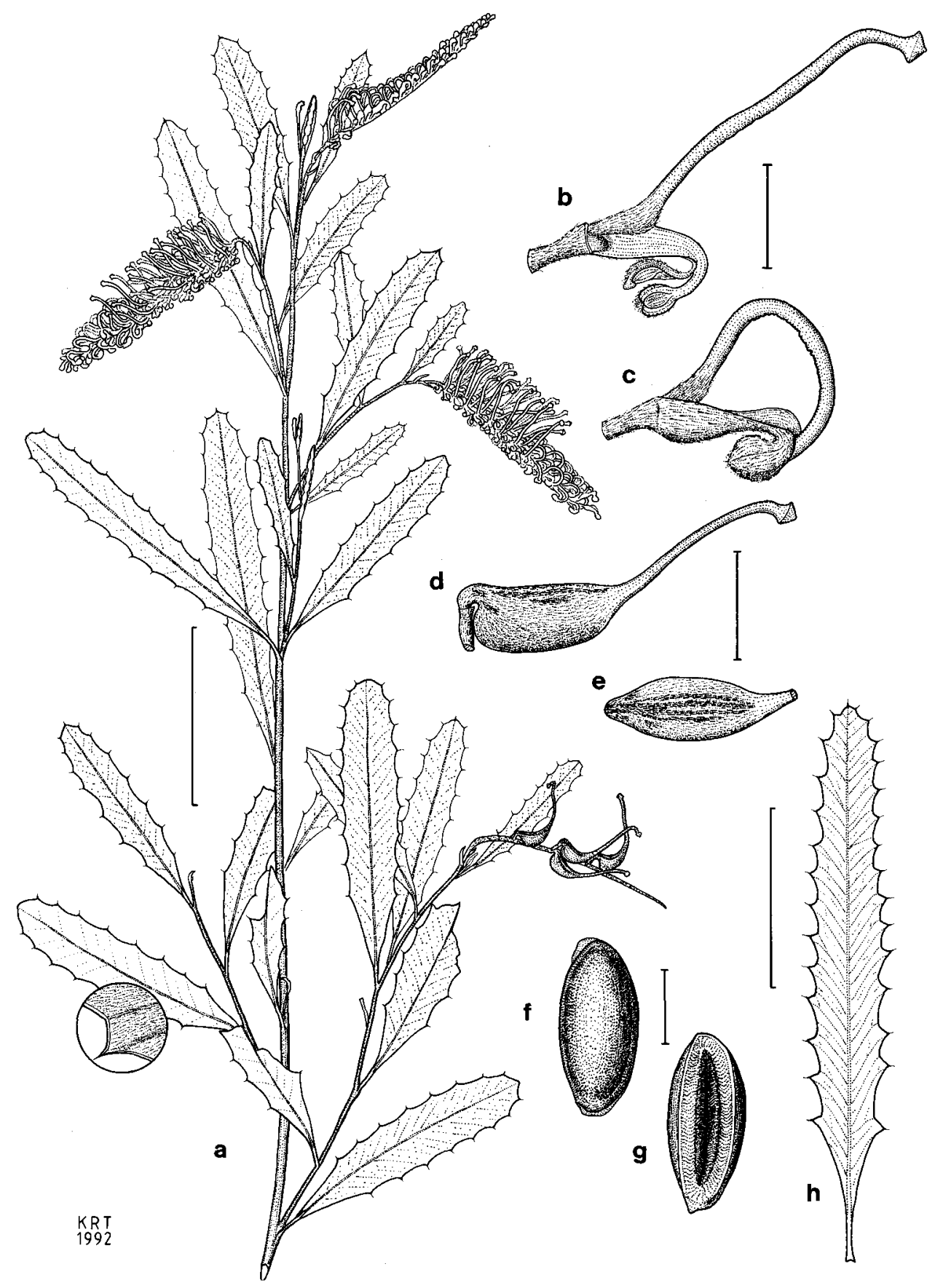

Figure 1. Grevillea wilkinsonii. a, flowering branch (inset showing sericeous undersurface of leaf); b, flower, half perianth removed to show ovary and nectary; $\mathbf{c}$, late bud; d, e, mature follicle, side and dorsal views, showing dorsal indumental striping; $\mathbf{f}, \mathbf{g}$, mature seed, outer and inner faces respectively; $\mathbf{h}$, leaf from 'Lacmalac' population, showing relatively greater length and tooth number. Scale bars: a, h, $5 \mathrm{~cm} ; \mathrm{b}, \mathrm{c} 4 \mathrm{~mm}$; d, e, $10 \mathrm{~mm} ; \mathrm{f}, \mathrm{g} 3 \mathrm{~mm}$. a, f, g from Makinson 865. Holotype; b, c from Makinson 870; d, e from Makinson 1020 (all from 'Goobarragandra' population). $\mathrm{h}$ from Makinson 875 ('Lacmalac' population). 
$<90^{\circ}$ ). A less consistent tendency to difference is in conflorescence length (rachis 40$55 \mathrm{~mm}$ long in 'Goobarragandra', against $20-40(-50) \mathrm{mm}$ in 'Lacmalac').

The existence of these differences between such close populations could be interpreted as evidence either for considerable and long-term genetic isolation of the two genomes, or for a survivor/founder effect from a more recently disrupted distribution; see discussion below under 'Habitat and ecology'.

A non-populational instance of variation in the 'Goobarragandra' population is the occurrence on at least one plant (permanent-tagged as 'clone 17') of flowers with normal (arcuate, integral) nectaries and other flowers with the nectary deeply divided to, or near to, the base of the nectary tissue, forming two or three distinct subtriangular lobes, each of which may be erose or toothed near the apex. This condition is unusual in Grevillea; disrupted nectaries have been noted as isolated abnormalities in a number of species, although in G. rubicunda S. Moore and an undescribed sister taxon (both from Arnhem Land) the consistent condition of four completely distinct nectary lobes around the torus has, along with other characters, led McGillivray (1993) to regard these two taxa as a distinct genus. In G. wilkinsonii, however, there is no reason to regard these multipartite nectaries as anything other than an abnormality or perhaps as an unstable but definitely derived character state.

FLOWER COLOUR AND ODOUR: Perianth outer surface brownish to reddish pink or purple, overlain with predominantly silver hairs; inner surface of perianth (partly exposed from late bud stage) lilac-pink deepening to almost black below the curve; anthers and pollen yellow; nectary yellow-cream, drying reddish; ovary greenish, overlain with a predominantly white indumentum with reddish hairs forming dorsal stripes; style lilac-pink, paler after anthesis and with the apical 1-3 $\mathrm{mm}$ straw-yellow; styleend and pollen-presenter straw-yellow. Flower coloration is noticably stronger on parts of plants growing in full sun. Flowers with a strong, sickly, mousey (amine?) odour. Most fertile plants are quite floriferous.

AfFinities: G. wilkinsonii is a member of the 'toothbrush-inflorescence' group of species of Grevillea, defined by Bentham (1870: 419) as Section Hebegynae (type species: G. pteridifolia Knight); the group is best characterised by a declined perianth tip in bud, a glabrous inner surface of the perianth, a hairy ovary, and the predominantly pale indumentum of the mature ovary and fruit with distinct stripes or blotches formed by aggregations of reddish hairs. Most members of the group have red, orange or yellow styles more than $2 \mathrm{~cm}$ long and are thought to be primarily birdpollinated; a few members (G. ramosissima Meisner, G. triternata $R$. Br., G. willisii R.V. Smith \& McGillivray) have shorter styles and share a (probably derived) insectpollination syndrome. G. wilkinsonii appears to share this reduction in flower size and pollination strategy.

Some 25 species of the Section occur in south-eastern Australia. On comparative morphological grounds the closest affinities of $G$. wilkinsonii are likely to be with G. willisii or with the larger-flowered species G. longifolia R. Br., G. barklyana F. Muell. ex Benth., and perhaps G. acanthifolia A. Cunn. The most distinctive features of G. wilkinsonii (compared to its south-east Australian congeners) are the simple, narrowly oblong serrato-dentate leaves, and the relatively short-styled deflexed inflorescences.

The species came to attention too late for inclusion in either the Flora of New South Wales (Makinson 1991) or the revision of the genus (McGillivray 1993). Modifications to the keys in those two publications may be made as follows in order to accommodate G. wilkinsonii. 
In Makinson (1991), G. wilkinsonii keys directly to artificial Group 6 (p. 39), then may go to either lead 1 or lead $1^{*}$. After lead 1, change lead 2 to read ' 2 Branchlets more or less angular ...'; G. wilkinsonii and G. longifolia will both key on this lead. To distinguish between the two, add a further couplet directly after lead 2:

2a Pistil 21-24 mm long; leaf apex more or less acute; styles red ... 6 G. longifolia

2a* Pistil 14-15 mm long; leaf apex obtuse with a weak point; style lilac-pink .... G. wilkinsonii

Specimens not agreeing with lead 1 on leaf length, will then proceed via leads $1^{*}, 3^{*}$, $5,6^{*}$. To identify the species it is necessary to add a couplet $6 \mathrm{a} / 6 \mathrm{a}^{*}$, directly after lead $6^{*}$ :

6a Leaves narrowly oblong, $<25 \mathrm{~mm}$ wide, margin regularly spino-dentate with the teeth up to $4 \mathrm{~mm}$ long, pistil 14-15 mm long; style lilac-pink. .... G. wilkinsonii

$6 \mathrm{a}^{*}$ Leaves not as above, variously shaped and strongly lobed or if with regular marginal teeth then these $>5 \mathrm{~mm}$ long; pistil > $18 \mathrm{~mm}$ long; style pink, red, or purplish black.

(Then resume key at lead 7).

In McGillivray (1993), G. wilkinsonii keys initially to Key Group 9 (p. 32) then may go to either lead 1 or lead $1^{*}$. After lead 1, change lead 2 to read '2 Branchlets more or less angular ...'; G. wilkinsonii and G. longifolia will both key on this lead. To distinguish between the two, add a further couplet directly after lead 2:

2a Pistil 21-24 mm long; leaf apex more or less acute; styles red 6 G. longifolia

$2 a^{*}$ Pistil 14-15 mm long; leaf apex obtuse with a weak point; style lilac-pink ....

G. wilkinsonii

Specimens not agreeing with lead 1 on leaf length will then proceed via leads $1^{*}, 3^{*}$, 12 , and may go to either 13 or $13^{*}$. Following lead 13 , add a couplet $13 a / 13 a^{*}$ as follows:

13a Leaves narrowly oblong, margin regularly spino-dentate with the teeth up to 4 $\mathrm{mm}$ long, pistil 14-15 mm long; style lilac-pink

G. wilkinsonii

$13 a^{*}$ Leaves not as above, variously shaped and strongly lobed or if with regular marginal teeth then these mostly apical; pistil $<12 \mathrm{~mm}$ long or $>18 \mathrm{~mm}$ long; style pink, red, yellow to orange, or purplish black.

(Then resume key at lead 14).

To accomodate specimens keying via lead $13^{*}$, add a couplet $15 \mathrm{a} / 15 \mathrm{a}^{*}$ immediately after lead 15, as follows:

15a Leaves narrowly oblong, $<2.5 \mathrm{~cm}$ wide; undersurface of leaves with a dense sericeous indumentum (appressed straight hairs); margin flat ...... G. wilkinsonii

$15 \mathrm{a}^{*}$ Leaf shape and indumentum either not as above (oblong to ovate or angularly obovate, 1-6 cm wide, and undersurface with a more or less open indumentum of curly hairs), or if narrowly oblong and $<2.5 \mathrm{~cm}$ wide, then undersurface glabrescent or with an open indumentum of appressed straight hairs and margin shortly recurved.

(Then resume at lead 16). 
Distribution ANd CONSERvation status: New South Wales, Southern Tablelands botanical district, but at only 320-350 m altitude and fairly close to the South-west Slopes district boundary, and in a zone of vegetation associations intermediate between those characteristic of the two districts. The species is known from only two populations with a total of about 150 plants, in the Goobarragandra Valley south-east of Tumut. Exact locations are omitted from this paper to minimise casual collecting; full details may be obtained through the New South Wales National Parks and Wildlife Service.

The species is highly endangered, and (as Grevillea sp. 'Tumut') has been given a ROTAP coding of $2 \mathrm{E}$. The known populations are directly threatened by floods, weeds (including blackberry infestation), possible browsing by domestic and feral stock, road widening, and roadside herbicide spraying. Longer term problems include subdivision of the valley to smaller properties with tenure and management complications. Several of the immediate threats have been mitigated by joint action between the authorities having tenure and management of the upstream population: co-operation between Tumut Shire Council, the Gundagai Rural Lands Protection Board, and the Tumut River Electricity authority, mediated by the N.S.W. National Parks and Wildlife Service and staff of the Australian National Botanic Gardens, has resulted in fencing of most of this population and an awareness of the problems of roadworks and herbicides. The bulk of both populations remains at threat from extreme flood events, with perhaps $80 \%$ of plants at $2 \mathrm{~m}$ or less above normal river height; six fully adult plants are known to have been killed by moderate floods in the winter of 1991.

The species is the subject of a draft management and recovery plan being co-ordinated by the N.S.W. NPWS, with funding allocated by the Endangered Species Unit of the Australian NPWS.

HaBitat AND ECOLOGY: The two known populations both occur at around 320-350 m altitude, on flood terraces and adjacent slopes of the Goobarrabandra River, a sizable permanent river running north-west from the Kosciusko massif. Geology of the area is complex; the valley is bounded to the north-east by Lower Devonian Burrinjuck Granite and to the south-west by Middle Devonian Bogong Granite assemblages. The floor of the valley, now mostly cleared, is underlain by these types and by high grade ultrabasic metamorphics closely associated with outcrops of the Devonian Coolac Serpentine belt (Ashley et al. 1971). Plants of the (upstream) 'Goobarragandra' population occur primarily on a coarse-grained rock (?granodiorite), with a few plants on a serpentinite bluff; many plants of this population, which is the more floodprone, have their roots anchored in crevices in hard-rock exposures; they are absent from adjacent shingle banks. Plants of the 'Lacmalac' population are in colluvial or alluvial soil over an orange granitic species. Most of the serpentinite exposures in the valley have been cleared for grazing; Lyons et al. (1974) note that soils of the Coolac Serpentine Belt are characteristic of ultrabasic environments in having high associations of iron-group elements (cobalt, chromium, iron, manganese and nickel) and magnesium, and low levels of calcium and potassium. Given the unusual geology of the valley and low-nutrient edaphic status of ultrabasic environments, and the general pattern of Australian Proteaceae to exhibit species richness in low-nutrient and edaphically anomalous situations, the possibility of in-situ speciation of G. wilkinsonii from a more widespread ancestor should be considered, as distinct from the alternative view of the present distribution as being relict. The strict edaphic preference of the fairly closely related G. caleyi R. Br., a Sydney Basin endemic confined to residual pseudo-lateritic substrate with a high iron-minerals content (Hunt et al. 1977) is an interesting parallel. 
The present location of most plants in the flood zone of the river may not represent an original preference for riparian habitat, nor one for granitic rather than serpentinitic substrates, but rather a local refuge following post-settlement clearing. Some extant plants grow on serpentinite, and some are upslope from the river in drier and more open situations, and have new seedlings establishing there. On the other hand, much apparently suitable and relatively undisturbed habitat both along the river and on the slopes lacks the species. The tendencies to morphological difference between the populations, noted above, may imply that the species has for a long period had only a patchy and discontinuous distribution, although genetic isolation over evolutionary time of two such close and insect-pollinated populations seems unlikely; perhaps more likely is that the extant populations are largely in-breeding lineages from a relatively recent (probably post-settlement) disruption of a more or less continuous distribution, the populational differences being accounted for by founder effect of the survivors from the originally variable population. If the latter is the case, a very narrow genetic base could be anticipated within each extant population.

Original vegetation of the valley floor can only be judged by remnant patches, but was primarily eucalypt forest, with E. blakelyi and E. macrorhyncha dominant. Present vegetation of the riparian zone and adjacent slopes includes those two species, and dense patches of Leptospermum sp. aff. brevipes and L. obovatum, with Hakea microcarpa, Acacia implexa, A. sp., Dodonaea viscosa subsp. ?spatulata, Pomaderris angustifolia, $P$. sp., Bursaria spinosa, Callistemon sieberi, Calytrix tetragona, Lomandra longifolia, and adventive weedy species including heavy infestations of Blackberry (Rubus fruticosus), White Willow (Salix alba), Briar Rose (Rosa rubiginosa), and Paspalum distichum.

Both populations show a healthy age structure, with roughly $25 \%$ of plants being classable as old (> 8 years?), $50 \%$ as intermediate and fertile, and $25 \%$ as nonreproducing juveniles. No signs of lignotubers or root-suckering were noted; these strategies are not common in the 'toothbrush-inflorescence' group of the genus. The species propagates easily from cuttings. In common with most of its closer relatives, G. wilkinsonii is likely to be fire sensitive, regenerating primarily from seed. Neither site has been burnt in the last decade, and one or two older plants have developed trunks up to $4 \mathrm{~m}$ long, although the plants have collapsed to a lesser overall height. Life span of the species is likely to be about $10-20$ years.

Flowering is prolific, although concentrated in an unusually (for a grevillea) narrow time-band of October-November, with a weak second flush in autumn. Pollinating agents are unknown, but probably insects are the main vectors; many species of bees (native and exotic) and flies and small beetles were observed visiting the flowers. The mousey floral odour suggests the possibility of some mammalian pollination as in some Western Australian Banksia species with a similar smell, but marsupial response to odours as such is undocumented, and they seem unlikely to be a major vector given the continuing good reproductive rate despite clearing of surrounding habitat. Nectar production is obvious, particularly early in the day.

To judge from the age structure and the summer of 1991-2, fruit and seed set is apparently at fairly high levels, albeit with much variation from plant to plant. Seed viability appears good, but field estimates of seedling age, and initial nusery trials of seed germination, indicate a 6-10 month minimum dormancy period; fruit ripening is in November-December, but new seedlings have only been noted in spring over the two seasonal cycles so far studied. Fruit and seed predation is quite high, with very many fruits broken by birds or small mammals littering the ground; fallen ripe seeds are rapidly scavenged by ants, perhaps for the waxy elaiosome material, and two instances were noted of multiple seedlings growing out of ant nests. 
Selected SPECimens: New South Wales: Southern Tablelands: banks of Goobarragandra River ... along road to Goobarragandra from Tumut - Wee Jasper turnoff, Ollerenshaw 1807, 28 May 1991 (CBG 9102972, MEL, NSW); ... ESE of Tumut, Goobarragandra River ..., R.O. Makinson 1020 \& C. Jordan, 22 Dec 1991 (CBG 9107021, NSW), Makinson 875, G. Butler \& W. Molyneux, 9 Nov 1991 (CBG 9106657, AD, BRI, MEL, NE, NSW); ... Goobarragandra River, S bank ..., Makinson 1181 \& P. Zeising, 1 Oct 1992 (CBG 9213930, DNA, GAUBA, MEL, MO, NSW, PERTH, RSA), Makinson 1182 \& P. Zeising, 1 Oct 1992 (CBG 9213931, AD, BRI, K, MEL, NE, NSW).

\section{Acknowledgements}

Michael Crisp and Lyn Craven for assistance with the Latin diagnosis; Ian Telford and Faye Davies for comments on the manuscript; Kevin Thiele for the illustration; Geoff Butler, Catherine Jordan, and Faye Davies of the ANBG, and John Briggs of CSIRO, for assistance with field work; John Brown and Tumut Shire Council, and Ian Pulsford and Geoff Winnett of the N.S.W. NPWS, for organising prompt protective measures in the face of impending roadworks. Special mention of Ian Pulsford and John Brown for standing in front of the grader on an early visit to the site, and of the County Council grader driver (name unknown), who listened.

\section{References}

Ashley, P.M., Chenhall, B.E., Cremer, P.L. \& Irving, A.J. (1971) The geology of the Coolac serpentinite and adjacent rocks east of Tumut, New South Wales. J. \& Proc. Roy. Soc. New South Wales 104: 11-29.

Bentham, G. (1870) Flora Australiensis, vol. 5 (L. Reeve: London).

Makinson, R.O. (1991) Grevillea. Pp. 31-55 in Harden, G.J. (ed.) Flora of New South Wales, vol. 2 (University of N.S.W. Press: Kensington).

Hunt, P.A., Mitchell, P.B. \& Paton, T.R. (1977) "Laterite profiles" and "lateritic ironstones" on the Hawkesbury sandstone, Australia. Geoderma 19: 105-121.

Lyons, M.T., Brooks, R.R. \& Craig, D.C. (1974) The influence of soil composition on the vegetation of the Coolac serpentinite belt in New South Wales. J. \& Proc. Roy. Soc. New South Wales 107: 67-75.

McGillivray, D.J. (1993) Grevillea (Proteaceae) A Taxonomic Revision (Melbourne University Press: Melbourne).

Manuscript received 13 October 1992

Manuscript accepted 10 February 1993 